Jeffrey J. Schott is a senior fellow with the Institute for International Economics. Copyright: Institute for International Economics, 2000. All rights reserved.

\section{Toward WTO 2000: A Seattle Odyssey}

\author{
Jeffrey J. Schott
}

$T^{\prime}$ rade ministers from the 135 member countries of the World Trade Organization (WTO) reconvened in Seattle in December 1999 to assess the operation of the trading system and to initiate a comprehensive new round of multilateral trade negotiations. The meeting ended in disarray and without action on the trade agenda. The new round is in abeyance, even though new WTO negotiations on agriculture and services will get underway in 2000 as preordained in the WTO's so-called "built-in" agenda.

Anti-WTO protesters claimed credit for disrupting the Seattle meeting and blocking the launch of a new trade round. In large measure, however, the WTO meeting fell victim to serious substantive differences both among developed countries and between developed and developing countries regarding what should be on the agenda for the new WTO Round.

In essence, everyone wanted to liberalize foreign trade barriers, but not their own. The major trading nations were reluctant to address their own barriers to trade in goods and services, while demanding that new talks target protectionism in the developing world. The developing countries argued that new concessions should await the fulfillment of liberalization committed during the previous Uruguay Round. Some wanted priority to be given to implementation of existing WTO accords and "traditional" trade issues such as tariffs and anti-dumping; others wanted the agenda broadened to encompass new subjects like electronic commerce and labor standards. No one wanted protracted talks like those which occurred in the previous Uruguay Round, but no one seemed able to craft a practical negotiating agenda that accommodated the diverse and often divergent interests of developed and developing countries.

Some of the biggest problems, however, involved disputes among the United States, European Union, and Japan over farm subsidies, competition policy, and anti-dumping. The major trading nations did not seem to have enough support from their domestic constituencies to actively negotiate and put a deal together. In the United States, the five-year long impasse over fast-track authority inhibited discussion of possible U.S. trade reforms. In Europe, monetary union and enlargement issues already presage important economic and institutional reforms and made countries reticent to undertake new trade obligations that would entail additional adjustments, especially in agriculture.

In brief, short-run political concerns now dominate the trade debate and counsel caution. Longrun benefits from prospective accords are simply too far away to hit the radar screen of elected politicians. Trade officials will need to work hard to overcome political resistance to new trade reforms, at home and abroad, so that substantive negotiations can proceed.

I cannot do justice in this paper to the complexities of the problems that I have just outlined. Their implications stretch well beyond the realm of trade policy. But, I can try to offer a few insights on the value of international trade negotiations and the particular importance of proceeding promptly with a new WTO Round of multilateral trade talks. To that end, this paper addresses why new negotiations are needed, what needs to be included on the negotiating agenda, what is in it for developed and developing countries, and how the negotiations should proceed.

\section{WHY A NEW ROUND IS NEEDED NOW}

In many respects, the launch of a new WTO Round is now even more important in 2000 than it was in Seattle, in part to remedy the substantive and institutional problems exposed during the December meetings. New global trade talks are needed for several reasons.

First, WTO talks would provide a useful buffer against growing protectionist pressures in the United States and Europe directed against increased imports from emerging markets. To date, we have not seen significant protectionist legislation in the United States, despite a record U.S. merchandise trade deficit of almost $\$ 350$ billion in 1999 . The one notable exception has been the failed steel quota bill. However, there has been a growing resistance to new trade initiatives, as evidenced by the continuing impasse over the renewal of fast-track author- 
ity. ${ }^{1}$ As the U.S. economy slows and unemployment increases from its current low levels, protectionist demands are likely to proliferate.

In addition, aftershocks from the 1997-99 financial crisis continue to be felt in Latin America as well as in Indonesia and Thailand, which have lagged the Asian recovery. The crisis has not provoked a sharp increase in import restrictions in those countries, but it has dampened political support-at least in the near-term-for new trade reforms. WTO talks are needed to help get that reform process back on track and to reinforce medium-term growth prospects in those markets.

Second, public support for the WTO and an open international trading system needs to be shored up. In several major trading nations, the WTO is under attack. Public concerns about the effects of globalization (including expanded trade and investment) on domestic production and employment, and on national regulatory policies in areas such as labor and the environment, threaten to undercut support for new WTO initiatives in the United States and other countries. Some groups regard WTO provisions as part of the problem (e.g., rulings against enforcement provisions of U.S. environmental laws); other groups want to refocus WTO obligations so that they help meet other economic and social objectives (e.g., promoting human rights and higher labor standards), even if the WTO is not the primary channel of action. Governments will face increasing problems in sustaining political support for new trade talks if the traderelated aspects of these issues are not addressed more effectively in the WTO.

In that regard, the WTO's free-trade principles increasingly have been contested with respect to products developed through new biotechnologies. In particular, trade in genetically modified organisms (GMOs) has raised concerns about the longterm impact of these new products on human health and the environment, and led several countries to ban or segregate the sale of these products in their markets. The WTO requires that such restrictions must be underpinned by sound scientific evidence of potential harm, but WTO critics argue that by the time the evidence is in, the harm will have been done.

Third, the implementation of the WTO's dispute settlement understanding (DSU) has exposed a number of problems that need to be corrected. For example, the recent banana and beef hormone cases highlighted the flaws in the compliance provisions of the DSU; other dispute rulings (e.g., FujiKodak case regarding competition policy issues) have pointed out other gaps in the trading rules. The dispute resolution system has to be fixed to maintain confidence in the enforcement of WTO obligations, and new negotiations are needed to remedy the notable omissions and ambiguities in existing WTO provisions that have been exposed by dispute cases.

Fourth, WTO members need to correct a few of the WTO's serious birth defects, particularly regarding the management structure of the organization, linkages with other international institutions, and the transparency of WTO operations. For example, the WTO lacks a management or steering committee akin to the Executive Board of the International Monetary Fund (IMF) and the World Bank. The Quad (i.e., the United States, the European Union, Japan, and Canada) has assumed this role, but will have difficulty in maintaining it as WTO membership expands to countries such as China. In addition, the financial crisis has underscored the need for closer cooperation between the WTO and the IMF and World Bank to provide trade expertise in the negotiation of reform packages and to ensure that such reforms are maintained (via binding in WTO schedules). ${ }^{2}$ New negotiations need to correct these institutional problems in the WTO system.

Fifth, the WTO's built-in agenda already mandates new negotiations by 2000 on both agriculture and services, along with a number of other important issues ranging from government procurement to subsidies. However, the built-in agenda is not sufficient to produce a successful trade accord and will need to be supplemented if negotiations are to succeed. Long-standing General Agreement on Tariffs and Trade (GATT) experience demonstrates that self-standing negotiations on agriculture never succeed; recent services accords have fared somewhat better (but only when developing countries accepted deals that did not require significant changes in U.S. and European practices). ${ }^{3}$ In short, a broader bargain will be needed to allow countries to trade off

\footnotetext{
${ }^{1}$ In addition, protectionist pressures weighed heavily in President Clinton's decision in April 1999 to reject the Chinese market access proposal in its effort to join the WTO, and in Congressional adoption of restrictive textile trade preferences for the Caribbean Basin and Africa in May 2000.

${ }^{2}$ Similarly, closer ties between the WTO and the International Labor Organization could further understanding of how world trade can help promote better working conditions and living standards in WTO member countries.

${ }^{3}$ Since the end of the Uruguay Round, WTO members have concluded accords on basic telecommunications and financial services, and on information technology products. Talks failed on maritime services and on the movement of natural persons.
} 
concessions across sectors and issues and undertake obligations to liberalize long-standing and politically sensitive trade barriers. If the WTO does not undertake a more comprehensive negotiation than that set forth in the built-in agenda, the talks will likely fail and, in so doing, also weaken credibility in the multilateral negotiating process.

To address these problems, WTO members also will have to redress the serious resource constraints that already hamper WTO activities. The Uruguay Round accords greatly expanded the responsibilities of the WTO but member countries have not provided adequate resources to service new trade negotiations, administer the burgeoning caseload of disputes, conduct trade policy reviews and complex accession negotiations, and collaborate with the World Bank and the IMF regarding trade reforms of countries in financial crisis. Staffing constraints already limit the scope of cooperative efforts with the IMF and the World Bank to help promote "greater coherence in global economic policymaking." Such efforts are particularly needed to assist the least developed countries and countries in transition to fully integrate into the world trading system.

WTO members need to allocate more funds and perhaps additional authorities to the WTO's Director General and Secretariat to better handle these tasks. The WTO budget is less than $\$ 80$ million and has not grown much since 1995, despite the enormous increase in demand for services by the Secretariat and by panelists and judges in the dispute settlement body. At a minimum, industrialized countries should immediately double their WTO budget contributions (which would mean an extra \$12-14 million annually for the United States). There is no reason why some specialized United Nations (UN) agencies should receive more funds than the world's principal trade forum.

Contributing to many of the problems cited above are ongoing efforts to bring new members into the world trade club. Increased membership will further tax the WTO's limited resources and exacerbate management problems. Before turning to the substance and process of prospective WTO talks, I will divert briefly to summarize a few key aspects of the accession process that have a bearing on the WTO negotiating agenda.

\section{THE WTO ACCESSION PROCESS}

To be a truly global system, the WTO should strive for universal membership. To date, progress toward that goal has been good-but not good enough.
As of January 2000, the WTO has 135 memberscompared with 91 GATT signatories at the start of the Uruguay Round. In addition, 30 countries have applied for membership and initiated the accession process.

The accession of new members to the WTO is not as easy as it used to be under the GATT. Candidate countries face more comprehensive obligations covering both trade measures imposed at the border and domestic policies that influence trade in goods and services. At the same time, special exceptions for developing countries have been sharply cut back. The entry bar has been elevated to record heights just as the demand for WTO membership has increased dramatically.

Negotiating the protocols of accession for prospective WTO members often is a long, tedious process (and, in a few cases, highly politicized as well). Countries seeking WTO membership come from diverse backgrounds and economic systems, and their accession protocols must be tailored to their particular situation:

- Six countries are classified by the UN as "least-developed."

- Eleven countries are former components of the Soviet Union, including Russia.

- Four countries are former Eastern European components of the Council of Mutual Economic Assistance: Albania, Bosnia and Herzegovina, Croatia and Macedonia.

- Three countries are relatively well-off Persian Gulf states: Saudi Arabia, Jordan, Oman.

- Five others present diverse challenges: Algeria, Andorra, Seychelles, Tonga, and Vietnam.

- Two are highly politicized: China and Taiwan.

In general, WTO members would like to expedite the accession process of these countries, and to give special terms for the poorest applicants. However, the trade regimes of the majority of the candidates do not conform easily to the WTO system.

The basic choice confronting WTO members is to approve entry for many of these countries on terms that allow extended and flexible implementation of WTO obligations; or to hold back on entry as a lever to induce the changes in national policies needed to meet WTO standards. Either way, new members should adhere to all WTO obligations; the only difference is whether they should be active members of the WTOand subject to WTO reporting and monitoring-while they reform their policies.

Interestingly, 29 of the 135 WTO members are classified by the UN as "least-developed" and pre- 
sumably least capable of implementing the comprehensive trade obligations, including the substantial administrative and reporting requirements, of the WTO accords. Note, however, that some WTO provisions explicitly exempt the least-developed developing countries from specific obligations (such as the ban on export subsidies). The six least-developed countries currently seeking admission to the WTO should be expected to do no more than these current members. To promote their accession, WTO members need to offer greater technical assistance to support efforts by applicants to adapt their trade regimes to WTO norms and to guide their officials through the accession process.

\section{THE NEGOTIATING AGENDA}

To meet the challenges noted above, new WTO negotiations will have to pursue several initiatives simultaneously:

- Trade liberalization that contributes to the sustained recovery from the recent financial crisis and blunts demand for new protection;

- New rule-making that establishes rights and obligations in areas not yet subject to, or inadequately covered by, WTO provisions; and

- Institutional reforms that remedy flaws in the WTO's dispute settlement and management structure, that make WTO operations more transparent, and that help promote economic development for the betterment of all citizens of WTO member countries.

Developed and developing countries will have different interests in each of these areas and place different priorities on liberalization versus rulemaking initiatives. To take into account the broad range of perspectives of WTO member countries, the agenda for new WTO negotiations will have to be comprehensive, addressing both the new issues that pose problems for global commerce in goods and services, as well as the systemic issues that threaten to undercut public support for future WTO initiatives. The following subsections highlight some of the key substantive issues that need to be covered in new WTO talks.

\section{The WTO Agenda: Existing Mandates}

Agriculture and services are the twin pillars of the WTO's built-in agenda. Oddly, that agenda omitted tariff reform - the bread and butter of all eight previous rounds of multilateral trade negotiations. Given historical precedent and the desire of WTO members to continue to build on past efforts in this area, I will also discuss tariff liberalization as well as its alter ego, anti-dumping reform, in this section.

\section{Agriculture}

The Uruguay Round accord provided one of the few commitments to lower farm trade barriers, albeit to a limited extent, in the post World War II period. That multilateral negotiation succeeded because negotiators could "ante up" a large array of foreign concessions to "pay" for the liberalization of hard-core farm trade barriers. Recall that the Uruguay Round pact on agriculture only succeeded when negotiators linked commitments on intellectual property and textiles to those on agriculture.

WTO members committed in the Uruguay Round to restart negotiations by the year 2000 to promote "progressive reductions" in agricultural support and protection. Each country has a different idea what this means, but all generally support the liberalization of other countries' trade barriers and subsidies. Reducing subsidies or import barriers protecting domestic farmers will require, as it did in the Uruguay Round, significant trade-offs between agriculture, manufacturing, and services reforms.

Not surprisingly, the agenda for agricultural reforms is extensive. The Uruguay Round barely scratched the surface of trade barriers protecting national markets, and the new negotiations will focus primarily on building upon those tentative liberalization efforts. Much work remains, in particular, to reduce subsidies, lower tariffs, liberalize tariff-rate quotas (TRQs) and other nontariff barriers. In addition, WTO members will have to decide how to handle the expiry in 2003 of the "peace clause" that restrains many farm trade disputes.

Export subsidies remain a problem despite significant cutbacks agreed upon in the Uruguay Round. The Cairns Group and the United States have proposed eliminating export subsidies. To temper such demands, the European Union has argued that U.S. farm export credits should be included under the existing disciplines. Domestic subsidies were also reduced in the last round, but many countries argue that these disciplines are being circumvented via flexible interpretations of "blue box" and "green box" exceptions (that is, subsidies that are allowed because they are not linked 
to production or not deemed to be trade distorting). ${ }^{4}$ Tariffication in the Uruguay Round made some protection more transparent, but resulted in many duties in triple digits; indeed, "dirty" tariffication arguably raised some barriers to trade. In addition, in areas where countries made minimum access commitments, improved guidelines are needed to prevent countries from administering TRQs in a manner that further limits access to their markets. Finally, WTO members need to review the growing number of non-tariff measures imposed in support of national health and safety regulations to determine whether revisions are needed to the agreement on agriculture, sanitary and phytosanitary measures, or possibly even a sui generis pact on biotechnology.

At the same time, countries need to develop clear and narrow guidelines for exceptions to liberalization efforts in order to promote specific non-trade objectives related to the "multifunctionality" of agriculture. Many countries argue that they must sponsor some level of agricultural activity to protect the environment, promote biodiversity, enhance rural economic development, and maintain food security. In so doing, however, WTO rules need to be crafted to guard against the introduction of new non-tariff barriers under the guise of broader non-trade objectives.

\section{Services}

The Uruguay Round developed a framework of multilateral rights and obligations on trade in services but left much work undone. Recognizing the limitations of their initial effort, WTO members agreed in Article 19 of the General Agreement on Trade in Services (GATS) that new negotiations would be launched by January 2000 to put more flesh on the skeletal provisions and commitments previously negotiated.

The services negotiations are one of the most critical components of the WTO agenda. Services are important both as stand-alone products and as critical inputs for the production of a wide range of goods and other services. Improving productivity in service sectors can thus yield extensive growth dividends throughout member economies. In that regard, these talks are particularly important for developing countries to help them improve their financial sector, and telecommunications and transportation networks. ${ }^{5}$

Much of the attention of these negotiations will focus on attempts to liberalize trade in particular sectors, although the agenda also will be cluttered by issues left over from the Uruguay Round (subsidies, safeguards, and government procurement in services) and by a number of important but intractable constitutional problems (for example, the relationship between the market access and national treatment chapters). Efforts need to be directed toward building on the very limited liberalization agreed in the basic telecommunications and financial services pacts, broadening reforms to new sectors such as environmental, energy, and entertainment services, and revisiting politically sensitive areas, such as maritime and labor services.

Unfortunately, negotiations on services will face several critical problems. First, unlike recent talks on basic telecommunications and financial services, developed and developing countries will have different export interests in the various sectors under negotiation. Developing countries place priority on removing barriers in sectors where they are competitive, such as labor and entertainment services; developed countries favor their own "winners" such as audio-visual, air transport, information, and professional services. "Priorities" of some countries are "non-starters" for others. Second, and more generally, the positive list approach to scheduling commitments, along with the ability of countries to limit the application of those offers to one of the four modes of supply, will continue to constrain the scope and value of liberalization commitments.

\section{Tariffs}

Tariffs continue to be a mainstay of the WTO agenda, despite notable success in prior rounds in reducing levies imposed by industrial countries to relatively low average levels. Tariffs imposed by developing countries remain generally high, although the Uruguay Round made significant progress in binding a large share of those duties for the first time. Several problems are left over from past GATT efforts that should be addressed in the new WTO round, including:

- "Peak" tariffs on selective products at levels

\footnotetext{
${ }^{4}$ For example, some countries argue that U.S. disaster relief programs, that amounted to more than \$6 billion in 1998, offset the subsidy cuts mandated in the U.S. Freedom to Farm Act.

${ }^{5}$ For example, to improve competitiveness of the tourism sector, countries need access to global telecommunications and information services for marketing and reservations, and an efficient transportation network to get the people to the market.
} 
well above the average country tariffs, and the related problem of tariff escalation.

- Tariff bindings at rates well above those currently applied that allow governments free reign to raise duties for protectionist purposes without WTO review.

To address these problems, countries traditionally have developed a tariff-cutting formula to implement tariff reductions across the board. In practice, however, such an approach quickly degenerates into a productby-product negotiation of exceptions to the so-called "formula cuts," which is why we still have a problem with peak tariffs and tariff escalation. The Uruguay Round experience with "zero-for-zero," sector-specific tariff cuts suffered the same problem, as countries carved out products or entire product categories from the liberalization list. To date, the United States has proposed accelerated tariff liberalization (really elimination) in eight sectors, but seeks to avoid a formula approach to limit the exposure of its high apparel tariffs to new tariff cuts. ${ }^{6}$ As a practical matter, there is no real difference between the two approaches since both will necessarily devolve into intensive negotiations over exceptions to the general approach on a product-by-product basis.

\section{Anti-dumping}

Trade remedy laws provide a safety valve for countries that liberalize their trade barriers. The WTO allows its members to impose temporary import relief (up to four years, with one four-year extension) if imports threaten or cause serious injury to domestic industry, and more lengthy and indefinite (subject to five-year reviews) protection if imports benefit from subsidies or are dumped and cause material injury.

Anti-dumping is one of the few legal ways for countries to impose protection unilaterally (that is, without WTO clearance), and it has become the favored import relief measure for a growing number of countries. In the past, anti-dumping laws were virtually the exclusive domain of the United States, European Community, Canada, Australia and New Zealand. Since the end of the Uruguay Round, however, new users (primarily developing countries) have accounted for many more cases than the five traditional users. Indeed, over the period 1993-1997, Mexico and Argentina have reported almost as many anti-dumping actions as the United States. More than two-thirds of anti-dumping actions have been directed against developing countries and countries in transition during the 1990s, illustrating why this is a priority concern for those countries.

Prospective WTO negotiations on anti-dumping measures face an uncertain outlook. The Singapore Ministerial in 1996 agreed to examine the "interaction between trade and competition policy, including anti-competitive practices"-which many countries defined as encompassing anti-dumping actions. These countries hoped that U.S. interest in the latter would allow consideration of constraints on antidumping measures because those actions reduce competition almost by definition (if one assumes that the action is not directed against predatory practices, as is almost never the case). Instead, the linkage has generated opposition by the United States to new talks in both areas. Incremental revisions to existing provisions of the Anti-dumping Agreement are the most that could be expected from new talks; too many countries value their recourse to these measures to stem "unfair" import competition.

\section{Broadening the WTO Agenda}

WTO member countries have put forward a lengthy list of potential new subjects for negotiations. Several of the new issues actually date back to the charter for the stillborn International Trade Organization of the late 1940s, although they have assumed added importance in a era of globalization. To a very modest extent, almost all are the subject of WTO rules or ongoing working groups. Many involve activities that go well beyond the scope and competence of the WTO. For that reason, WTO initiatives in these areas must be narrowly focused on the trade-related aspects of each issue and have clearly defined and pragmatic (i.e., achievable) negotiating objectives.

Four topics have been frequently cited as candidates for new WTO talks: investment, competition policy, labor, and the environment. In addition, electronic commerce has gained attention due to the rapid growth in international transactions via the internet.

\section{Investment}

The Uruguay Round touched only lightly on investment issues in the Agreement on Trade-

\footnotetext{
${ }^{6}$ The eight sectors, originally discussed in the Asia-Pacific Economic Cooperation forum, cover chemicals, forest products, medical equipment and scientific instruments, environmental goods, energy, fish, gems and jewelry, and toys.
} 
Related Investment Measures (TRIMs) and in the limited areas where countries undertook specific commitments on "commercial presence" in the GATS. Many investment issues are not subject to WTO disciplines; investment incentives and export performance requirements, for example, continue to distort trade and investment flows among WTO member countries. Given the recent experience in the Organization for Economic Cooperation and Development (OECD) with negotiations on a "Multilateral Agreement on Investment," and the heated opposition that it generated among nongovernmental organizations, many countries are wary of engaging in broad WTO negotiations in this area (Graham, forthcoming 2000). Instead, they would like to continue the incremental approach to rulemaking within the existing WTO pacts. The WTO has three options for dealing with investment issues:

- First, WTO members could promote further progress on breaking down investment barriers by expanding the list of prohibited measures in the TRIMs accord to include inter alia joint venture and technology sharing requirements as well as export performance requirements.

- Second, WTO negotiators could continue to use the GATS talks to expand investment disciplines to a broader range of service activities.

- Third, WTO negotiators could craft a new "Agreement on Direct Investment" that would establish a common framework of rules for goods and services. Ideally, such an accord would provide both most-favored nation and national treatment to foreign investors (with exceptions for national security and a few other narrowly defined sectors) as well as disciplines on investment incentives. In so doing, a WTO investment pact would also reinforce the objectives of talks on competition policy, since more open investment regimes promote competition in the domestic market.

Given the importance of foreign direct investment (FDI) for the growth of key sectors in developing economies, these countries should champion the cause of comprehensive investment rules in the WTO (Moran 1998). Most developing countries already recognize the value of FDI in transferring technology and management skills to their economies and have instituted investment reforms that have substantially opened their markets to foreign investors (with a few notable sectoral exceptions).

\section{Competition Policy}

At its core, the WTO is about competition policy writ large. Its aim is to create opportunities for firms to trade and invest in foreign markets, adding a healthy dose of competition for domestic producers. National practices differ, however, in their approach to what constitutes a "healthy" level of competition, and many countries do not have a body of competition law at all. Competition laws and regulations can affect both the entry and distribution of goods and services in a market by encouraging or discouraging market concentration and restrictive business practices. Makers of airplanes and telecommunications equipment already know how such regulatory policies can foreclose export opportunities, but current WTO provisions provide little recourse.

For these and other reasons, competition policy poses complex problems for WTO negotiators. Many countries have difficulty in just crafting internal consensus on trade and competition objectives; forging an international consensus from differing national legal structures and regulatory regimes will be even harder. For that reason, I am sympathetic to the approach proposed by Graham and Richardson (1997), who argue that WTO efforts in this area should be handled in small, incremental steps. The first step should be procedural, with an agreement that competition-policy authorities would consult with their counterparts in other WTO countries about practices that impede the access of foreign investors or exporters. Over time, closer contacts between trade and competition officials could produce more integrated policies, including the development of baseline common standards (starting with cartels and mergers) that could be codified in a new pact on trade-related antitrust measures.

Nonetheless, the new WTO Round could make progress on competition policy rules in narrowly focused areas. For example, the WTO already has developed a set of regulatory guidelines that establish competition rules for the basic telecommunications sector. As with investment issues, further progress might be possible in specific service sectors building on that precedent.

\section{Environment}

The WTO has been discussing environmental issues since its inception under the auspices of the Committee on Trade and the Environment (CTE). Unfortunately, the CTE has made little progress in defining an agenda for WTO negotiations. Provisions 
relating to environmental matters in GATT Article $\mathrm{XX}$, and the standards and the sanitary and phytosanitary agreements are ambiguous and have precipitated several high-profile disputes (e.g., tunadolphin and shrimp-sea turtle cases). Rulings in these cases found that certain enforcement provisions of environmental laws were in violation of WTO obligations; ideally, the panels also should have clarified issues and areas of WTO law where existing rules are inadequate and need to be supplemented to deal with the problems under dispute.

What should be done? First, the WTO agenda in this area should develop procedures within the CTE to examine the environmental implications of existing and new WTO initiatives. Second, countries should negotiate reductions in subsidies that distort trade and generate adverse effects on the environment. For example, agricultural subsidies have promoted overproduction in some regions with adverse effects on soil and water resources. Similar concerns arise in the energy, forestry, and fishery sectors. Third, sector-specific initiatives that promote liberalization of environmental goods and services should be given priority. Finally, WTO talks should revive the generally failed efforts of the CTE to formulate WTO guidelines with respect to eco-labeling and to promote the conformity of WTO rules with multilateral environmental agreements.

\section{Labor}

Labor issues are highly contentious among WTO members and also provoke vocal and substantive concern among WTO critics. The 1996 Singapore Ministerial clearly rejected WTO negotiations on labor issues, deferred to the International Labor Organization (ILO) regarding the strengthening of international labor standards and enforcement mechanisms, but recommended that the two secretariats continue their existing (albeit minimal) cooperation. Since that time, WTO discussion of labor standards has been consistently blocked by developing countries; in fact, the ILO has not even been accorded observer status in the WTO (unlike several other international agencies). However, the ILO has produced several notable agreements on labor standards, including the June 1999 Convention on the Elimination of the Worst Forms of Child Labor.

All countries want their workers to enjoy higher standards of living and cleaner and safer working environments; few tolerate having other countries impose trade sanctions because of their domestic labor policies. ILO members have agreed on a number of Conventions and "principles concerning the fundamental rights which are the subject of those Conventions," and that these "universal rights" should be promoted by all countries. However, there is no agreement on what steps countries should take to implement and enforce those rights, much less whether different standards should apply in countries at vastly different levels of development.

In brief, WTO countries do not have a common view of what trade-distorting labor practices should be subject to WTO obligations or how to determine whether they exist in particular situations. As a result, WTO provisions provide no objective standard by which dispute panels can judge the compliance of national labor practices with WTO rights and obligations (with the exception of GATT Article XX provisions relating to prison labor). No wonder developing countries are reticent to discuss WTO enforcement measures against abusive labor practices.

The new WTO Round will probably not be able to solve that complex problem, but it can promote better understanding of potentially trade-distorting labor practices and cooperative initiatives by the WTO and the ILO to improve working conditions in their member countries. Given the residue of ill will among many WTO members from previous U.S. efforts in this area, new initiatives in this area would have to start with a modest agenda. As I have previously proposed (Schott 1998), the first steps should be procedural and aim to codify the nascent, informal process evolving between the WTO and ILO. A joint committee of the WTO and ILO Secretariats should be commissioned to examine both the relevance of GATT provisions to labor issues and what could be done in the WTO to promote higher labor standards (both carrots and sticks). ${ }^{7}$ Reports from this committee could then inform future discussions and negotiations in both organizations.

\section{Electronic Commerce}

The rapid growth in the virtually unregulated domain of electronic commerce should command the attention of WTO negotiators. Here, a dose of preventive medicine is in order. At the May 1998 WTO Ministerial, member countries agreed not to

\footnotetext{
${ }^{7}$ For example, WTO members could consider "green lighting" labor training subsidies (i.e., exempting them from countervailing duties) to facilitate adjustment and create new opportunities for trade in relatively labor-intensive products.
} 
impose tariffs on electronic commerce for one year. This standstill agreement should be extended so that a work program can be fully developed in both the GATT and GATS context that addresses the real and potential distortions to the "production, distribution, marketing, sale or delivery of goods and services by electronic means" arising from domestic regulatory policies.

\section{WHAT'S IN IT FOR THE UNITED STATES?}

The United States has been the leader of the postwar world trading system and remains so today. U.S. officials are at the center of efforts to develop an international consensus on the terms of reference for the new WTO negotiations. These efforts are hampered, however, by sharp divisions within and between U.S. political parties regarding the issues and objectives that should be given priority in the WTO talks. The five-year old impasse over fast-track authority reflects these differences, and complicates efforts to consolidate political support for U.S. requests and offers in new negotiations. Indeed, the United States has not made significant changes in its trade practices since the inception of the WTO, and is reticent to discuss reductions in its remaining trade barriers in the context of prospective WTO agreements.

As a practical matter, the United States will not be able to "free ride" on the WTO Round as it did in the recent services and information-technology pacts; it will have to offer concessions if the talks are to succeed. Nonetheless, the United States has much to gain from a successful package of WTO accords.

First, new WTO agreements would help secure greater access to foreign markets for U.S. exports of goods and services. Overall, foreign trade barriers are significantly higher than those protecting the U.S. market; like the Uruguay Round package, U.S. trading partners will undertake much more extensive liberalization commitments than the United States. In particular, U.S. trading interests would benefit from reforms in the following areas:

- Industrial tariffs: Reducing foreign levies down to U.S. levels and/or eliminating tariffs entirely sector-by-sector (including the eight sectors in Asia-Pacific Economic Cooperation (APEC) forum's accelerated tariff liberalization proposal, and an Information Technology Agreement II). - Agricultural reforms: Eliminating or sharply reducing export subsidies; substantially reducing domestic subsidies and clarifying criteria for blue and green box programs; cutting tariffs; and strengthening disciplines on the administration of tariff-rate quotas and operation of state-trading enterprises.

- Services: Building on the modest liberalization achieved in the Uruguay Round on a sectorspecific basis with a focus on both infrastructure and financial services, and on new areas, such as environmental services where U.S. firms are world leaders.

- E-Commerce: Maintaining duty-free treatment of electronic transmissions, and advancing a WTO "work program to ensure technological neutrality in the development of WTO rules, and capacity-building efforts to ensure that developing countries have access to the Internet" (Esserman 1999, p. 6).

Second, WTO accords will hopefully promote more effective compliance with WTO accords, and improvements in the WTO system "to make the organization more transparent, responsive, and accessible to citizens" (Esserman 1999). Several WTO initiatives would work toward these goals, including:

- Strengthening the dispute-settlement understanding, particularly the compliance provisions.

- Improving the transparency of WTO operations, including the publication of documents on a timely basis, increased inputs from interested parties in dispute settlement cases, and better means for "stakeholder organizations" to share their views with WTO delegations.

- Promoting transparency in national procurement systems through adoption of WTO core principles in this area.

Third, WTO accords help promote the adoption of market-oriented reforms in countries negotiating accession. Strengthening the rights and obligations of the trading system through new WTO accords provides useful guidelines for future policy reform in China and the other countries seeking admission to the world trade club.

Fourth, to broaden public support in the United States for overall WTO initiatives, the United States would like to strengthen WTO initiatives dealing with labor and environmental issues. U.S. objectives in these areas are modest compared with earlier proposals, but still face strong opposition from developing countries. On labor, the United States would like to establish a forum for discussing trade and 
labor issues as part of a broader effort to promote compliance with internationally recognized core labor standards. Environmental objectives are less contentious since they build on existing provisions and initiatives in the WTO, and seek to promote environmental reviews of trade pacts as well as reform of trade practices (e.g., subsidies) that cause environmental problems.

In sum, the United States has broad-based economic and political interests in a successful WTO Round. Most of its objectives involve liberalizing foreign trade barriers down to U.S. levels and strengthening WTO rules so that foreign trade laws and regulations move up toward U.S. norms.

What trade reforms can the United States contribute to the party? While the U.S. market is arguably the most open in the world, there are a few notable barriers whose partial liberalization could yield large dividends both in terms of foreign trade concessions and U.S. economic welfare. U.S. negotiators will probably be pressed to accept reforms in three main areas:

- Reductions in peak tariffs (including textiles and clothing), perhaps capped at a level of 15 percent or below;

- Reductions in agricultural protection, including cuts in domestic subsidies and enlargement of tariff-rate quotas on sugar, citrus and dairy products; and

- Constraints on the application of antidumping duties.

\section{WHAT'S IN IT FOR DEVELOPING COUNTRIES?}

One of the main objectives of trade negotiations over the past two decades has been to integrate developing countries more fully into the world trading system. For most of the GATT era, developing countries were, to a large extent, "free riders" not bound tightly to GATT disciplines. The single undertaking of the Uruguay Round substantially changed this imbalance by requiring developing countries to accept all the negotiated agreements, including those containing provisions that would be difficult to implement in the prescribed time period (such as the implementation and enforcement of intellectual property laws and other regulatory policies).

Since the 1980s, developing countries have undertaken much more substantial trade reforms, and bound much of them in their WTO schedules, than their trading partners in the developed world. Since their trade barriers remain, on average, higher than those in North America, Europe, and Japan, the results of new WTO negotiations will likely also require greater liberalization by the developing countries. From a mercantilist perspective typical of past GATT rounds, one could question the potential value of the new trade pacts; but from a development perspective, these deals have immense importance for developing countries.

Why then is it so important for developing countries to participate actively in new WTO negotiations? The answer is not simple because there is no monolithic position among the large number of developing countries that participate in WTO talks. Unlike the first seven rounds of GATT negotiations, developing countries now have widely differing priorities and interests depending on their level of development, on their obligations under regional integration initiatives, and on their dependence on trade in agriculture and commodities, manufacturing, or services. Coalitions among developing countries (such as the Caribbean Regional Negotiating Mechanism and the G-15), and between groups of developed and developing countries (e.g., the "Friends of the Round") now devise common positions that attempt to bridge the gap between developed and developing country interests. Recognizing this diversity, let me nonetheless outline what developing countries need from the new talks and a few reasons why they may not ask for it. ${ }^{8}$

First, and most fundamental, developing countries gain from the strengthening of the rules-based multilateral trading system. As the weaker partners in the trading system, they benefit the most when the major trading powers play by a common set of rules. In the Uruguay Round, for example, the willingness of the United States and Europe to accept dispute rulings and constrain their unilateral trade actions provided a major benefit for developing countries. The need to ensure compliance with those rulings is, in turn, of critical importance for the integrity of the WTO system.

Second, WTO negotiations help developing countries undertake and "lock in" reforms needed to advance their development objectives. Ideally, developing countries will implement trade and other reforms unilaterally because it is good for them; but, as a practical matter, most countries have

\footnotetext{
${ }^{8}$ For a more extensive analysis of developing country interests in the new WTO Round from somewhat different perspectives, see Krueger (1999) and Srinivasan (1999).
} 
difficulty removing the "muscle" of protection (say, the final 10-percent tariff) without securing support from other sectors of the economy that would gain from negotiated trade reforms in other countries. Simply put, reciprocal trade pacts (in the WTO and among regional partners) are an important part of the political economy of policy reform in developing countries.

Third, WTO accords could help advance agricultural liberalization in the OECD area, especially in regard to cuts in subsidies and high tariffs, that would be difficult to achieve outside the context of a large trade bargain. Of course, some developing countries would like to maintain protection for specific products (e.g., Korean rice), and some would like to continue to import subsidized goods that do not compete against local production, but overall they would benefit from increased access to industrial markets for products such as sugar, beef, and fruits and vegetables. In several instances, however, the greatest source of potential growth in developing country exports would come in areas of greatest import sensitivity in the OECD area.

Fourth, developing countries would gain from cuts in peak tariffs in OECD countries, particularly in the textiles and clothing sector. Reductions in textiles tariffs is particularly important in light of the imminent demise of quotas in 2005 , increased competition from China after it accedes to the WTO, and to dilute the value of preferences granted suppliers under customs union and free-trade agreements. Here again, their demands confront strong protectionist lobbies in the OECD area. Moreover, developing country demands in this area will spur reciprocal requests that their tariffs either be reduced or bound at the current applied rates.

Fifth, developing countries have much to gain from new rules and liberalization in specific service sectors. In many countries, the development of new service sectors, and strengthening the competitiveness of existing industries (e.g., tourism), could open important new growth areas and employment opportunities. For example, the growth of E-Commerce could become a viable part of development strategies if countries can improve their infrastructure services, especially telecommunications. Foreign investment in those sectors will be critical in that regard; thus, developing countries also will gain from WTO investment rules that would reinforce the dramatic opening that has been achieved in their markets over the past decade. In addition, labor services will be an important, albeit contentious, topic for the new round. Given immigration concerns, however, such talks are unlikely to advance unless WTO talks are narrowly focused by type of worker and conditions of employment.

Sixth, developing countries would benefit, like everyone else, from reforms in anti-dumping rules that constrain the overzealous use of these measures in a growing number of WTO countries. As the Uruguay Round demonstrated, however, reform of the arcane and detailed regulations guiding the administration of national anti-dumping laws is a complex task that can yield perverse results. Incremental reforms offer better prospects for success; small economies and the least-developed countries would especially benefit from the expansion of the safe harbor provisions (e.g., de minimis thresholds) for developing country exporters.

The above arguments present a strong case for active participation by developing countries in the new WTO Round. In several areas, however, specific export gains depend on the willingness of developed countries to pare down long-entrenched barriers in their least-competitive industries. Many developing countries are skeptical based upon the experience with the implementation by OECD countries of their Uruguay Round commitments, and the failure of recent WTO negotiations on movement of natural persons. With some justification, they question whether key Uruguay Round reforms (e.g., elimination of apparel quotas), that were "back-end loaded" and not scheduled to be fully implemented until 2005, will actually be liberalized. Conversely, some developing countries worry that the liberalization of those barriers will create new competition for their exporters and actually reduce their market share. In addition, some developing countries are less committed to anti-dumping reform because they are new and extensive users, and have created domestic interests that favor expanding this channel for the provision of import relief.

Finally, developing countries will continue to seek special arrangements in WTO accords to accommodate problems related to their development status. The Uruguay Round accords pared back the scope of such "special and differential" (S\&D) provisions that previously exempted poorer countries from key GATT obligations. Least-developed countries continue to receive large-scale and permanent exemptions (e.g., from disciplines on subsidies); other developing countries should not be given special treatment. Such provisions tend to distort investment within those economies and deter needed policy reform and industrial adjustment. 
Instead, like all other WTO members, developing countries should accept common obligations, but be afforded on a case-by-case, or sector or product-specific, basis different transition periods for the full implementation of those obligations (just as developed countries were accorded 10 years to phase out their textile quotas). In other words, "differentiated" treatment should apply only to implementation periods to reflect, for example, the particular needs of small economies. This is particularly important in some rule-making areas where developing countries need to develop the administrative or judicial capabilities to implement and enforce new trade disciplines.

\section{THE NEGOTIATING PROCESS}

President Clinton, among others, has criticized the long duration of past GATT rounds and suggested at the GATT's $50^{\text {th }}$ anniversary meeting in Geneva in May 1998 that "we must develop an open global trading system that moves as fast as the marketplace" (Clinton 1998). He recognized that WTO talks must produce concrete results in a timely fashion, or risk erosion in the support of pro-trade coalitions for the trade talks. That is the rationale behind the call of U.S. Trade Representative Charlene Barshefsky for a three-year deadline for new WTO negotiations.

Unfortunately, many trade officials still think of new WTO talks in terms of a fixed-length, one-shot GATT round, even though they admit that the old

GATT approach no longer fits the fast-paced world of global commerce. Instead, they should adopt a broader, yet more pragmatic, strategy for trade negotiations.

Fortunately, the WTO has already upgraded the GATT model; its new institutional framework accommodates continuous negotiations. WTO ministers can start and finish talks on some issues while other subjects remain under debate and new issues are added to the agenda. Trade ministers could use their regularly scheduled meetings as action-forcing events to put together a package of trade agreements in what I have called a "round-up" (see Schott 1998). In this way, countries can conduct a series of seamless trade negotiations, with new talks starting immediately after a package of trade agreements is concluded. Each round-up would build on the results of the previous accord. Over a decade, the WTO could produce three or four round-ups, which cumulatively liberalize significant trade barriers and strengthen member countries' rights and obligations.
To implement this strategy, WTO talks will have to encompass a broad range of issues. Some trade officials worry that WTO talks will bog down if negotiators cover too many issues, including subjects that do not seem "ripe" for resolution in the near future. They fear that the requirement that the new round be a "single undertaking"-in which nothing is agreed until all aspects of the package of accords are agreed-would make it quite difficult to conclude new trade pacts promptly because negotiations in some areas will require many years to be fully resolved.

Such concerns reflect an outdated concept of "single undertaking" based on the old GATT model of trade rounds. Each set of agreements, or "roundup," would be a single undertaking, but would not require that all aspects of all issues under negotiation be completed before a deal could be concluded. Because the WTO is a forum for continuing negotiations, not all of the problems in a given sector need to be rectified in the first phase of talks or initial round-up, nor would each round-up have to include all issues. Each package, however, would have to include reforms of interest to both developed and developing countries, so that each member could "bring home" concessions that reinforce domestic political support for the trade pacts and for implementing reforms of their own trade barriers.

To be sure, such an approach still requires complicated "horse trading" among a large number of countries on a large number of issues. But crafting together such packages of agreements, I believe, is essential to accommodate trade-offs across sectors and issues, involving both product or sectorspecific liberalization and acceptance of new trade obligations. Without such grand bargains (even on the more limited scale envisioned by my round-ups), WTO members will likely fail to dent the strongest trade barriers protecting domestic industries in their key export markets. Nonetheless, the three-year timetable for the talks, as proposed by the United States and others, will clearly be ambitious, especially if the lack of fast track and electoral politics in 2000 limit the flexibility of U.S. negotiators to pursue reciprocal trade pacts.

\section{THE IMPORTANCE OF U.S. FAST-TRACK AUTHORITY}

For the United States, each round-up would require new implementing legislation that would be smaller than the voluminous bills associated 
with recent GATT rounds. Round-ups will thus increase the urgency of early reauthorization of fast-track authority.

To be sure, U.S. officials do not need fast-track authority to enter into new trade negotiations. Fasttrack is, in essence, a gentlemen's agreement between the Congress and the Executive to expedite the consideration of legislation implementing the results of trade agreements in return for Congressional approval of negotiating objectives and input into the negotiating process.

In the past, U.S. officials started trade negotiations without fast-track authority, but with the explicit understanding that such procedures would be in place well before the final stages of the talks. Today, however, Congressional approval at a later date cannot be assured. To the contrary, fast-track legislation has been defeated in the Congress and stands a low probability of passage in the next few years.

The five-year-old impasse over fast-track has two important implications for WTO talks. First, it raises questions about the depth of the U.S. political commitment to new trade initiatives. The reluctance of the Clinton administration to defend ongoing regional and multilateral trade initiatives against the critics of globalization within their own party in the run-up to the Presidential election in November 2000 underscores such concerns. Continuing differences among policymakers in both parties over the priority to be given to labor and environmental objectives in trade accords is part of this problem.

Second, it ties the hands of U.S. negotiators in preparing the agenda for new trade talks and limits prospects for multilateral accords. Whether they admit it or not, U.S. negotiators have been reticent to offer proposals that require significant changes in U.S. practices, policies, and trade barriers, particularly in areas such as agriculture, textiles, and anti-dumping and competition policy. Without a Congressional mandate, U.S. officials fear that such actions would galvanize widespread opposition to fast track renewal from a diverse coalition of business, labor, and nongovernmental organizations (NGOs). Unfortunately, this posture makes it hard for U.S. officials to be responsive to the priority objectives of other WTO members, particularly developing countries. Naturally, these countries respond in kind: Why expose one's own sensitive trade barriers to global talks if the major industrial markets seem unlikely to offer concessions in areas of greatest interest to them?
In short, U.S. trading partners interpret the impasse over fast-track as a sign of political opposition to reform of U.S. trade barriers and conclude that U.S. officials want to "free ride" on the next WTO trade accord. Some countries, such as India, go further and argue that these political constraints signal a desire to renege on past commitments to eliminate textile quotas (citing as evidence the recent U.S.-China WTO accession talks). Under these circumstances, the task of building an international consensus on a WTO agenda becomes increasingly difficult. Witness Seattle.

\section{REFERENCES}

Clinton, William J. Speech before WTO Meeting, Geneva, May 1998.

Esserman, Susan. "American Goals in the Trading System," testimony before the House Ways and Means Subcommittee on Trade, August 5, 1999.

Graham, Edward M. Antiglobalism and the Demise of the Multilateral Agreement on Investment. Washington, DC: Institute for International Economics, forthcoming, 2000.

and J. David Richardson, eds. Global Competition Policy. Washington, DC: Institute for International Economics, 1997.

Krueger, Anne O. "The Developing Countries and the Next Round of Multilateral Trade Negotiations," World Economy (September 1999), pp. 909-32.

Moran, Theodore H. Foreign Direct Investment and Development: The New Policy Agenda for Developing Countries and Economies In Transition. Washington, DC: Institute for International Economics, 1998.

Schott, Jeffrey J., ed. Launching New Global Trade Talks: An Action Agenda, Special Report 12, Washington, DC: Institute for International Economics, 1998.

and Jayashree Watal. "Decision-making in the WTO," Institute for International Economics Policy Brief 00-02 (March 2000). Washington DC: Institute for International Economics,

Srinivasan, T.N. Developing Countries in the World Trading System: From GATT 1947 to the Third Ministerial Meeting of WTO, revised draft of a paper prepared for the WTO's High Level Symposium on Trade and Development, Geneva, May 1999. 
RE V I E W

24 JuLr/AUGUSt 2000 